\title{
Technical Efficiency of Development Financial Institutions in Malaysia
}

\author{
Nazri Hashim, Mohd Faizal Basri*, Mohd Yahya Mohd Hussin \\ Faculty of Management and Economics, Universiti Pendidikan Sultan Idris, Tanjong Malim, Malaysia
}

Received April 17, 2021; Revised September 17, 2021; Accepted September 26, 2021

\section{Cite This Paper in the following Citation Styles}

(a): [1] Nazri Hashim, Mohd Faizal Basri, Mohd Yahya Mohd Hussin, "Technical Efficiency of Development Financial Institutions in Malaysia," Universal Journal of Accounting and Finance, Vol. 9, No. 5, pp. 1125 - 1133, 2021. DOI: 10.13189/ujaf.2021.090522.

(b): Nazri Hashim, Mohd Faizal Basri, Mohd Yahya Mohd Hussin (2021). Technical Efficiency of Development Financial Institutions in Malaysia. Universal Journal of Accounting and Finance, 9(5), 1125 - 1133. DOI: 10.13189/ujaf.2021.090522.

Copyright $(2021$ by authors, all rights reserved. Authors agree that this article remains permanently open access under the terms of the Creative Commons Attribution License 4.0 International License

\begin{abstract}
This study aims to identify the technical efficiency of Development Financial Institutions (DFIs) in Malaysia with the selected inputs of fixed asset and labour. Meanwhile, the output used in the study is financing. DFI is an institution that plays an important role in socio-economic development under the supervision of Bank Negara Malaysia (BNM). Using annual data from 2009 to 2018, technical efficiency is analysed using Data Envelopment Analysis (DEA) on the ten institutions selected in the DFIs. DEA results show that Sabah Development Bank Berhad (SDB) is the only institution considered as the most efficient. The rest of DFIs in the sample were deemed technical inefficient. The results also indicate that inefficient institutions including those with the lowest performance which are Credit Guarantee Corporation (CGC), Bank Pertanian Malaysia Berhad (Agrobank) and Bank Simpanan Nasional (BSN) have inefficient management in resource utilisation. Thus, activities in the operation of DFIs need to follow the law of return to scale for input and output orientation so that resources can be managed efficiently.
\end{abstract}

Keywords Technical Efficiency, Development Financial Institution, Data Envelopment Analysis, DFIs, DEA, Malaysia

\section{Introduction}

Socio-economic development is strongly promoted by the Malaysian government. This sector focus on underserve market that is less taken over by business activities from other commercial banks. The underserve market includes sector of agriculture, infrastructure, small and medium enterprises, maritime, export-oriented sectors and high-technology industries Bank Negara Malaysia [1]. These were led to introduction of institutional groups called as Development Financial Institutions (DFIs). DFIs have been monitored by Bank Negara Malaysia (BNM) since 2002 [2].

In 2015, BNM in new amendments started focusing on enhanced areas related to promoting greater efficiency in the operation of DFIs [3]. It is one of the initiatives to reduce the credit risk they are currently burdened with. In 2005, Credit Guarantee Corporation Malaysia Berhad (CGC), one of the non-prescribed institution, received a grant from the Malaysia Ministry of Finance for RM30 million to meet the possibility of non-performing financing [4]. Therefore, the latest amendments are intended to prevent them from relying on government fiscal injections [5]. However, these numbers are still out of control by DFIs. Hence, this study looked at the current level of efficiency for each DFIs by employing Data Envelopment Analysis (DEA) which is a non-parametric analysis from 2009 to 2018. DEA was chosen because of its flexibility, applicability for multi-input and multi-output variables, and widespread use in various studies, particularly in developing countries such as Malaysia [6-11]. Furthermore, the works in DEA have shown strong growth in terms of journal article publication, with a total of 10,300 articles 
published as of the end of 2016 [12].

DFIs is also one of the financial institution sectors in Malaysia that has received less attention than commercial banks, Islamic banks, and the takaful industry. Very few research studies have focused on DFIs in Malaysia, particularly using recent financial data, and this study will help to fill that gap.

\section{Overview of DFIs in Malaysia}

BNM monitored DFIs under the Development Financial Institutions Act 2002 (DFIA) as a framework for financial management [2]. It is divided into prescribed and non-prescribed institutions as shown in Table 1.

Table 1. List of DFIs in Malaysia

\begin{tabular}{|cc|}
\hline \multicolumn{2}{|c|}{ Prescribed Institutions } \\
\hline 1. & Bank Pembangunan Malaysia Berhad (BPMB) \\
\hline 2. & Small Medium Enterprise Development Bank Malaysia \\
Berhad (SME Bank)
\end{tabular}

Source: Bank Negara Malaysia, 2020

Based on various reports by Bank Negara Malaysia [13], financing offered by DFIs often depends on deposits due to most of the funds were funded by depositors. It was 66 percent from depositors and 3.8 percent from government which is an average from 2014 to 2018 . Between 2014 and 2018, value of depositors increased every year by an average of 5.7 percent. while the percentage change from 2017 to 2018 for deposit fund show the smallest contribution (2.6 percent: RM 5306.5 million) compared the year between 2014 to 2015 (11.1 percent: RM18320.1 million). Data also shows slow promotion of DFIs to achieve their objectives that includes to encourage the habit of saving among the various sectors of society such as small donors, cooperatives and Islamic depositors [14].

For overview of their target sectors developments, from 2014 to 2018, total financing accumulated by the DFIs shows three percent on average annual growth rate. This was observed in annual report by Bank Negara Malaysia [13]. However, the numbers are not consistent offered to the economic sector involved. For example, there has been no increase in financing over the three consecutive years (2016 to 2018) on the sector of electricity, gas and water supply, maritime sector, and transport, storage and communication sectors. In contrast, the agriculture, forestry and fishery sectors are seen as the most consistent sectors to grow until 2018 (RM 11,844.8 million) with growth of 10.2 percent compared to 2017 (RM 10,748.4 million). Somehow, the performance of that sector is a boost from the microfinance program launched in November 2017 for agricultural entrepreneurs of lower income group in Malaysia [1].

The government has consistently made regulation to ensure the management of DFIs is in control and run efficiently. These include amendments to corporate governance, tightening the criteria for appointment of CEOs, clearer roles of the Board and ministerial accountability, and enhancing accountability for compliance with bank-issued standards [3]. BNM also introduces a new area of upholding shariah compliance in the activities of DFIs. This is in line with the provisions of the Islamic Financial Services Act 2013 (IFSA). Accordingly, all institutions are seen to offer Islamic-based products and services to this day. In fact, all six institutions that have been gazetted as prescribed institutions under BNM now have their own shariah committee [15].

\section{Literature Review}

In order to remain competitive and relevant in the market, Malaysian banks, including DFIs, are increasingly comparing their performance to that of others. Various researchers use a variety of methods and techniques to assess the performance of financial institutions, including financial ratios, econometrics, and statistical models that examine efficiency [16]. According to Farrell [17], one of the components of efficiency is technical efficiency. Technical efficiency refers to a firm's capacity to handle a set of inputs in order to maximise output. [18]. A firm is considered efficient when the operation of the process from input to output is always along the production possibility frontier. The technical efficiency measure is to meet the law of constant returns to scale that represents overall technical efficiency (OTE). OTE determines efficiency based on input-output and operating size [19].

\subsection{Measures of bank efficiency}

In assessing performance, a variety of econometric 
methods and models are available. Mostafa [20] narrowed it down further, stating that the efficiency performance of banks is primarily assessed using the Stochastic Frontier Approach (SFA) (parametric) and Data Envelopment Analysis (DEA) methods (nonparametric).

SFA was introduced by Aigner, et al. [21]. It is a method that defines the cost and production function while also allowing for error terms. SFA evaluates efficiency by analysing inputs and outputs based on functionality. The method of analysis enables the researchers to explain the disparity between the banks' current and best performance. When describing SFA, Berger and Humphrey [22] described it as a functional form for a cost-profit-or-production relationship that allows for random errors. According to Kumbhakar and Lovell [23], SFA added the random shocks element to the model to account for factors such as weather changes or economic downturns that may impact the production process. Jawada and Siwar [24], Miah and Uddin [25] conducted studies on the relationship of efficiency in financial institutions in Asia and the Gulf Cooperation Council (GCC) using SFA.

Meanwhile, DEA is a technique that computes comparative ratios of outputs and inputs for each unit in relation to the efficiency score. This method analyses a firm's efficiency by using linear programming as the methods that use decision-making units (DMUs) efficiency frontiers [26]. One of the advantages of this approach is that it does not require specification of a function and is easier to calculate. In identifying the efficient units, DEA does not impose a fixed structure on the data, resulting in minimal specification error. It also employs an approach that can deal with a large number of variables and relationships [27]. However, it has the disadvantage of not accounting for all deviations from the best-practice frontier because it does not allow for noise to be taken into account [28] and assume that data is error-free [29]. If the data was tampered with, the findings could not be interpreted with confidence. DEA, like other analyses that rely on reliable data, is especially susceptible to incorrect data. The efficient units are used to determine the efficient frontier and have an impact on the efficient scores obtained under the frontier.

\subsection{DEA Analysis in DFIs}

Development industry has been focused by many countries. There also have specific institutions were established in their own country based on their developmental needs. In Malaysia, Yadav and Katib [10] studied the level of efficiency and determinants of nine DFIs operating in Malaysia from 2006 to 2012. BPMB and SCC are the most efficient among DFIs. For others inefficient DFIs, they were managerial inefficiency using inputs (total deposit; total expenses) and output (loan; net investment).

A study is conducted in Indonesia on Regional
Development Banks (RDBs) that have a similar role as DFIs in Malaysia. Studies from Lutfi and Suyatno [30] use the DEA and analysed using output of total loan, interest income, non-interest operating income from 2012 to 2017. The results show that most banks have not been efficient on the inputs consist of fixed assets, employee cost and total deposits

There are several studies that study the level of efficiency in microfinance institutions that play a role in developing small and medium industries. Among them, Widiarto and Emrouznejad [31] conducted a study of 231 microfinance institutions in the Middle East and north Africa (MENA), East Asia and the Pacific (EAP), and South Asia. Studies examined the comparisons between Islamic Microfinance Institution (IMFIs) and conventional (MFIs) using inputs (labour; operating expenses; portfolio at risk 30 days) and outputs (revenue; loan; number of borrowers). Through DEA testing, MFIs have a higher overall efficiency, financial efficiency and social efficiency than IMFIs. Studies have also found that loan scale portfolio affects all levels of efficiency.

Meanwhile, Efendic and Hadziahmetovic [32] studied the level of financial and social efficiency of microfinance institutions in Bosnia and Herzegovina from 2008 to 2015. Results from the DEA analysis show that financial efficiency is significantly higher than social efficiency using inputs (numbers of labour; total asset) and output (numbers of active borrowers; revenue; loan). However, the impact of the financial crisis on the microfinance efficiency in both countries declines. Somehow, efficiency recovery is seen slowly after the crisis.

Basri, et al. [33] looked into the efficiency of Malaysia's domestic and foreign Islamic banks. Total financing (loans) and other earning assets were chosen as the study's outputs, while total deposits (deposits and short-term funding), personnel expenses, and total equity were employed as inputs. Between 2008 and 2015, the study discovered that domestic Islamic banks were more efficient than international Islamic banks in the country.

Comparative studies of bank efficiency levels between countries have also been stated. Gao, et al. [34] studied the efficiency of twelve DFIs which are divided into high-income country, low-income country and middle-income country. DEA analysis using inputs (fixed assets; administration expenses; interest expenditure) and output (Interest income; total loan). DEA results show that multilateral DFIs within each country are more efficient than other DFIs, while tests from Tobit Model show profit and policy are the key factors in determining efficiency.

\section{DEA Model}

The definition of DEA is a guide to non-parametric linear programming [35]. It is a method of determining efficiency using relative points.[17]. Charnes, Cooper, and 
Rhodes (CCR) pioneered the use of DEA in 1978. The authors proposed a model with input orientation and assumed a constant returns to scales (CRS) assumption [36]. To be effective, CRS must be implemented when all firms are operating at their peak performance. Due to imperfect competition or financial constraints, a firm may not be operating at its optimal scale.. The CCR model, which measures technical efficiency, was improved by Banker, Charnes, and Cooper (BCC). According to Emrouznejad and Anouze [37], a bank's technical efficiency is assessed by the highest quantity of outputs that a bank can create from the available inputs. A perfect score is one (or 100 percent), and banks with less than that are deemed technically inefficient since they use more assets and equity to generate the same amount of earnings than banks with a perfect score.

The relative points showed the efficiency firms were located on the frontier and firms that are far from their relative points are less efficient. The efficiency measure of the variance states that value one is the maximum efficiency level, while value zero is null [38]. It is to look at the capabilities of a firm in DMUs [39], where DMUs describe ability of a firm to optimise its use of inputs and outputs [17]. According to Sufian [40], the more output is produced, the more probability of efficiency is achieved. because the DEA can show the ratio of weighted output to weighted input.

Charnes, et al. [26] describe the input and output position in the mathematical model of the firm for the technical efficiency in Model 1.

Model 1. Technical efficiency: a fractional programming model

$$
\operatorname{Max} h_{0}=\frac{\sum r u r y r j 0}{\sum i v i x i j 0}
$$

Subject to

$$
\frac{\sum r u r y r j}{\sum i v i x i j} \leq 1, j=1, \wedge, n(\text { for all } j)
$$

Where $y_{r}$ : represent output in DMU

Where $x_{i}$ : represent input in DMU

DEA input-oriented explains the concept of production function in economic theory [41]. The concept describes the minimum amount of input used to reach a certain level of output [42].

Farrell [17] explains that technical efficiency decisions can compare one organization to another with the same characteristics as the application of regulation or technology to the production function. However, decisions in technical efficiency are not flexible to external influences such as government policy and economic fluctuations [41]. Therefore, pure technical efficiency decisions are an alternative to such deficiencies. Generally, pure technical efficiency is a measure of management's performance in the process of transformation between input and output [38]. Banker, et al. [43] have described the formula of pure technical efficiency as follows:

$$
\text { Pure Technical Efficiency }=\frac{\text { Technical Efficiency }}{\text { Scale Efficiency }}
$$

The difference between technical efficiency and pure technical efficiency is that it refers to a situation where a firm has a scale of inefficiency over a period of time [38]. Scale efficiency is the ability of one firm compared to other firms to achieve economies of scale by operating the best scale in operations [10].

The method is used to calculate technical efficiency in constant return to scale (CRS) proposed by Charnes, et al. [26], while pure technical efficiency uses the variable return to scale (VRS) method by Banker, et al. [43]. Coelli, et al. [28] stated mathematic programming need to be solved to achieve the optimal weight of a firm. It can be solved by applying to linear programming such as the formula to form CRS equation in input-oriented as in Model 2.

Model 2. Technical efficiency: CRS linear programming program in input orientation

$$
\begin{gathered}
\min _{\theta, \lambda} \theta, \\
s t-y_{i}+Y \lambda \geq 0 \\
\theta x_{i}-X \lambda \geq 0 \\
\lambda \geq 0
\end{gathered}
$$

Assume that firm $I$ has $N$ inputs and $M$ outputs for $i$-th firm, $N$ inputs are represented by $x_{i}$, while output $M$ is represented by $y_{i} . \theta$ is the technical efficiency score of $i$-th firm. while $\lambda$ describes $I \times 1$ as a constant vector. It is a matrix description to solve problems in linear programming. According to Farrell [17], $\theta=1$ assures $\theta$ $\leq 1$ and proves technical efficiency because the point of production lies above the boundary. However, the CRS assumes that the DMU for each firm is at an optimum scale. This is a situation where CRS is inaccurate technical efficiency scores. Thus, Banker, et al. [43] developed a VRS model as an alternative to technical efficiency result that make by CRS deviations [28].

Therefore, VRS was used by researchers with the addition of firm elements in the CRS equation by Banker, et al. [43] in their input-oriented model as in Model 3.

Model 3. Technical efficiency: VRS linear programming program in input orientation

$$
\begin{gathered}
\min _{\theta, \lambda} \theta, \\
s t-y_{i}+Y \lambda \geq 0 \\
\theta x_{i}-X \lambda \geq 0 \\
I 1^{\prime} \lambda=1 \\
\lambda \geq 0
\end{gathered}
$$

The addition of $I 1$ in the VRS function is the vector unity of the $1 \times 1$ matrix. If a firm does not maintain its optimum scale, then the function of the vector will produce 
a greater score than CRS [44]. The difference is the finding of scale efficiency that affected the firm back then.

The equation for the output-oriented is almost the same as the input-oriented equation shown earlier. In contrast, the target point concentrates on the output that reaches the frontier efficiency [37]. Alharthi [38] provides a summary of input oriented and output-oriented descriptions. The study stated that the firm would handle some situations such as the firm would try to absorb the inputs and maximise output (output-orientation) by either raising or lowering the inputs and outputs simultaneously (input-orientation) but the use of inputs should be less than the output consumption.

\section{Methodology}

Akdogan [45] stated that the initial process for the DEA aims to make a selection of decision points. His study suggests several things that need to be emphasised in the selection of DMUs namely: (1) all decision points should operate in a similar environment; (2) the use of equal inputs and outputs for each institution; and (3) a similar set of resources. While inputs and outputs selection in DMUs have the characteristics consisting of: (1) having the same factors for each decision point; (2) cover all levels of activity in the industry and have performance criteria to be studied; and (3) are physical and measurable economic resources [45].

Boussofiane, et al. [46] argued that the minimum value of DMUs is determined based on the multiplication result between input and output. For example, the minimum DMUs for this study are three (one output multiplied by two inputs). While Golany and Roll [47] suggested that the minimum number of DMUs is twice the sum of the input and output sums. The minimum sample DMUs of this study are six (three total input outputs are multiplied by two). Dyson, et al. [48] suggested that the number of DMUs is twice the result of multiplying the input and output of six DMUs (squared for two inputs multiplied by one output). While Bowlin [49] suggests the rule of thumb is as follows:

\section{Minimum number of DMUs $=3 \times($ input + output $)$}

To meet all the requirements of the rule of thumb, this study uses two inputs and one output because the number of DMUs in this study is ten. In summary, all determination methods are met where Bowlin [49] requires a minimum of nine DMUs, Boussofiane, et al. [46] require a minimum of three DMUs, Golany and Roll [47]and Dyson, et al. [48] require a sample of minimum of six DMUs.

Once the input and output along with the DMUs data are compiled, the analysis needs to determine the selected DEA model, input or output orientation and type of DEA calculation.

For model selection, the study selected CRS and VRS models. As explained earlier, CRS result represents technical efficiency decisions, while VRS results characterise pure technical efficiency results. Differences in such results indicate the existence of scale efficiency. CRS and VRS are classifications for the DEA to compare the results of the study [45].

For the selection of input or output orientation, this study applies both orientations in the analysis. Based on the measurements of these two orientations, the test against CRS often showed similar results [44]. Based on the model assumption, it is stated the firm were always in the optimal scale. However, the results for output oriented to VRS are different from the input-oriented results test [44]. Tests needed to take into both of these orientations with assuming every DFIs were approach input and output in different ways. It is supported by Basri [16] and Forughi [41] that stated input and output orientations are very important in managing the quantity control of a firm.

DEA calculation selection has three ways namely first-stage, second-stage and multi-stage. This study uses multi-stage in DEA calculations. It is because, the first-stage could not complete the linear programming of Model 1 and Model 2 discussed earlier. The problem is, whether there is input and output slack in the equation. Where there will be a straight line parallel in the frontier meaning there are two possibilities of efficiency that cannot be determined more closely [44]. The solution for the second stage by Ali and Seiford [50] also has the problem where input and output slack cannot be combined in a minimal way. So multi-stage is used as the best treatment of slack. It is chosen because it is able to detect the most suitable combination of input and output points by running radial linear programming to find efficient projection points [44].

Finally, efficiency indicators are determined by the range from zero to one based on Farrell [17] measurement points. The range interprets institutions that are at number one (100 percent) are more efficient than institutions that are close to zero ( 0 percent) score.

\subsection{Sample, Data and Analysis}

This study employs panel data of financial statement derived from annual record extracted from Fitch Solutions database and respective financial institutions. The data include 10 DFIs from 2009 to 2018. The data analysed using DEAP software version 2.1 introduced by Coelli [44].

All six prescribed institutions have been analysed. However, only four non-prescribed institutions of the DFIs were included in the sample due to the unavailability of sufficient data for the others. The six prescribed institutional comprising of BPMB, SME Bank, EXIM Bank, Bank Rakyat, BSN and Agrobank. Meanwhile, the four non-prescribed institutions are CGC, MIDF, SCC and SDB.

In order to determine the variables, the study employed 
intermediation approach where DFIs act as intermediaries for the transfer of funds to customers. In the intermediation approach, the inputs consist of fixed assets and personnel cost, which will be used to produce financing (output) to the customers. Thus, specification of data input and output are summarised in Table 2 below.

Table 2. Summary variables and respective measurement

\begin{tabular}{|c|c|c|c|}
\hline \multicolumn{2}{|c|}{ Variables } & Measurement & Sources \\
\hline \multirow{7}{*}{ Inputs } & $\begin{array}{c}\text { Fixed } \\
\text { Assets } \\
\text { (FE) }\end{array}$ & $\begin{array}{c}\text { Measured by } \\
\text { non-current } \\
\text { assets }\end{array}$ & $\begin{array}{c}\text { Lutfi and Suyatno [30], } \\
\text { Gao, et al. [34], Bahrini } \\
\text { [51] }\end{array}$ \\
\cline { 2 - 5 } & $\begin{array}{c}\text { Labour } \\
\text { (PE) }\end{array}$ & $\begin{array}{c}\text { Measured by } \\
\text { total personnel } \\
\text { expenses }\end{array}$ & $\begin{array}{c}\text { Alqahtani, et al. [52], } \\
\text { Jiang and He [53] }\end{array}$ \\
\hline \multirow{7}{*}{ Output } & $\begin{array}{c}\text { Financing } \\
(F)\end{array}$ & $\begin{array}{c}\text { Measured by } \\
\text { total gross loan } \\
\text { and financing } \\
\end{array}$ & $\begin{array}{c}\text { Widiarto and } \\
\text { Emrouznejad [31], } \\
\text { Efendic and } \\
\text { Hadziahmetovic [32], } \\
\text { Anto, et al. [54] }\end{array}$ \\
\hline
\end{tabular}

\section{Empirical Results}

Through the analysis conducted, the results are compiled through technical efficiency results. Then the pure technical efficiency result is divided into input orientation and output orientation together with scale efficiency resultsfollowed by a return to scale showing the operating area of a DFIs.

As depicted in Table 3, the average results for CRS technical efficiency for overall DFIs show a low efficiency level at 29.2 percent. This is far from the efficiency production point at 100 percent. VRS results show that DFIs efficiency is also low at 58.9 percent (input orientation) and 52.7 percent (output orientation). while scale efficiency score considered low as well at 48.5 percent and 53.1 percent for input and output orientation respectively. We can say that the average results for DFIs are inefficient especially in CRS.

As for the individual DFIs, CRS results show that only SDB is considered efficient. The rest are inefficient with the bottom three are CGC at 0.9 percent, BSN at 6.8 percent and Agrobank at 7.9 percent. Through VRS results for input orientation showed that only Bank Rakyat, BPMB, MIDF, SCC and SDB have pure technical efficiency. While SME banks have the lowest pure technical efficiency at 12 percent. For VRS results in output orientation, only Bank Rakyat, BPMB and SDB are efficient. However, CGC is the least efficient at 3.0 percent efficiency level.

The results for scale efficiency show that only SDB is efficient in input orientation. While MIDF and SDB are efficient in output orientation. SDB may be successful in promoting financing and implementing corporate practices well. Similarly, MIDF's efforts to redesign some of its efforts such as being a more efficient financial services provider since 2000 until now may indicate some improvement in their performance. CGC (5.2 percent) and Agrobank (18.7 percent) were the least efficient DFIs for input orientation and output orientation respectively. Both firms need to be more sensitive to employee quality and asset management to provide more efficient services and products. The size of their operations may not at the optimal level since they have the lowest scale efficiency for the respective orientation.

The operating position shows that Bank Rakyat, BPMB, Agrobank, BSN, EXIM Bank and SME Bank are functioning in decreasing return to scale (drs) which explains that proportionate increase in their output is less than the proportionate increase in their inputs, while MIDF functions on the opposite operation which is increasing return to scale (irs). However, dual result found in SCC and SGC that functioning at irs and drs respectively at input and output orientation.

Table 3. Results of DEA

\begin{tabular}{|c|c|c|c|c|c|c|c|}
\hline DFIs & CRSTE & \multicolumn{2}{|c|}{ VRSTE } & \multicolumn{2}{c|}{ SCALE } & \multicolumn{2}{c|}{ Return to Scale } \\
\hline & & IO & OO & IO & OO & IO & OO \\
\hline Bank Rakyat & 0.203 & 1.000 & 1.000 & 0.203 & 0.203 & drs & drs \\
\hline BPMB & 0.591 & 1.000 & 1.000 & 0.591 & 0.591 & drs & drs \\
\hline Agrobank & 0.079 & 0.199 & 0.421 & 0.395 & 0.187 & drs & drs \\
\hline BSN & 0.068 & 0.178 & 0.353 & 0.382 & 0.193 & drs & drs \\
\hline EXIM Bank & 0.421 & 0.595 & 0.673 & 0.707 & 0.625 & drs & drs \\
\hline SME Bank & 0.107 & 0.120 & 0.276 & 0.895 & 0.389 & drs & drs \\
\hline MIDF & 0.147 & 1.000 & 0.147 & 0.147 & 1.000 & irs & - \\
\hline SCC & 0.299 & 1.000 & 0.368 & 0.481 & 0.813 & irs & drs \\
\hline SDB & 1.000 & 1.000 & 1.000 & 1.000 & 1.000 & - & - \\
\hline CGC & 0.009 & 0.173 & 0.030 & 0.052 & 0.306 & irs & drs \\
\hline Average & 0.292 & 0.589 & 0.527 & 0.485 & 0.531 & & \\
\hline
\end{tabular}

Note: crste $=$ technical efficiency from CRS DEA; vrste = technical efficiency from VRS DEA; scale = scale efficiency = crste/vrste; IO = input orientation; $\mathrm{OO}=$ output orientation 


\section{Conclusions}

The study analysed the technical efficiency of the ten institutions in the DFIs from 2009 to 2018 by using non-parametric approach i.e. DEA. Based on the analysis, technical efficiency could be improved by 70.8 percent by optimising the use of inputs. It is consistent with the recommendations of Yadav and Katib [10] who suggested in optimising the use of inputs in Malaysia's DFIs for the improvement of technical efficiency score. However, this decision ignores the elements of management performance and cost control. Therefore, further studies are required to explore that matter.

As suggested in the analysis, pure technical efficiency could be increased by 41.1 percent at the input-oriented level and 47.3 percent at the output-oriented level. VRS results make recommendations on each institution in practicing more efficient use of resources. Bank Rakyat, BPMB, Agrobank, BSN, EXIM Bank and SME Bank need to reduce the proportion of inputs to outputs. On the other hand, MIDF needs to improve the proportion of inputs to outputs. Whereas, SCC and SGC need to act according to the selected input and output orientation. This will help the institutions to improve the scale efficiency which should be increased by 51.5 percent at the input-oriented level and 46.9 percent at the output-oriented level. However, among the samples in this study, only SDB is considered technically efficient for each input and output usage together with scale efficiency. DFIs with lower scale efficiency such as CGC, MIDF and Bank Rakyat should hire fewer employees and place a greater emphasis on hiring higher-quality employees rather than depending on quantity as suggested by Basri, et al. [33].

A DFI can be technically inefficient if employing too many personnel to produce maximum outputs as compared to its competitors. DFIs need to continuously build their internal expertise and enhance their understanding of the sectors or segments through regular engagement with the industry as well as enhance industry analysis, and leveraging on the access to data within the government.

Furthermore, in order to become more competitive, smaller DFIs may place a greater emphasis on technology and digital reform. On top of that, DFIs must also consider the potential borrower's commerciality and creditworthiness, as well as the projects involved as a lender, while playing a more complementary and developmental role in facilitating the nation's socioeconomic objectives as mandated.

From policy maker's point of view, encouragement of merger between DFIs also can be a possible solution in improving the efficiency level, reducing approval process, and streamlining the operations. This may help to reduce the issue of high non-performing financing among DFIs. However, the idea of removing of mandates assigned to respective DFIs might open up competition among DFIs hence, can improve efficiency. This is not the right time to do it just yet. The socioeconomic aspects of providing facilities for the underserve key strategic sectors is more important in supporting nation's socioeconomic objectives.

Nevertheless, this study faces the limitation of not incorporating all the institutions listed in the BNM's website due to unavailability of data. This study can be further expanded by analysing the determinants of efficiency in DFIs such as the aspects of risk and capability which can be discussed in influencing efficiency. Further analysis on DEA such as Malmquist Total Factor Productivity analysis can also be conducted to identify productivity changes throughout the observation period.

\section{Acknowledgement}

This research has been carried out under the Fundamental Research Grant Scheme for Research Acculturation of Early Career Researchers [2019-0167-106-62 (RACER/1/2019/SS01/UPSI/1)] provided by Ministry of Higher Education of Malaysia. The authors would like to extend their gratitude to Universiti Pendidikan Sultan Idris (UPSI) that helped managed the grant.

\section{REFERENCES}

[1] Bank Negara Malaysia, "Financial Stability and Payment Systems Report 2017," Bank Negara Malaysia, 2018.

[2] Bank Negara Malaysia, "Financial Reporting for Development Financial Institutions," 2020.

[3] Bank Negara Malaysia, "Financial Stability and Payment Systems Report 2014," Bank Negara Malaysia, 2015.

[4] Credit Guarantee Corporation, Credit Guarantee Corporation Annual Report 2011, Credit Guarantee Corporation Berhad, Kuala Lumpur, 2012.

[5] S. Azman, "DFIs should strive for financial independence," The Edge Financial Daily, The Edge Malaysia, 2018.

[6] A. L. Anouze, "Efficiency of performance of banks in the Gulf region before, during and after crises (financial and political)," Islamic banking and finance - Essays on corporate finance, efficiency and product development, vol. 3, pp. 111-124, 2015.

[7] J. Johnes, M. Izzeldin, V. Pappas, "A comparison of performance of Islamic and conventional banks 2004-2009," Journal of Economic Behavior \& Organization, vol. 103, no. Supplement, pp. S93-S107, 2014.

[8] B. Y. Keskin, S. Degirmen, "The application of Data Envelopment Analysis based Malmquist total factor productivity index: Empirical evidence in Turkish banking sector," Panoeconomicus, vol. 60, no. 2, pp. 139-159, 2013.

[9] S. Srairi, I. Kouki, N. Harrathi, "The relationship between Islamic bank efficiency and stock market performance: 
Evidence from GCC countries," Islamic banking and finance - Essays on corporate finance, efficiency and product development, vol. 3, pp. 125-135, 2015.

[10] R. Yadav, M. N. Katib, “Technical Efficiency of Malaysia's Development Financial Institutions: Application of Two-Stage DEA Analysis," Asian Social Science, vol. 11, no. 16 , pp. 175-182, 2015.

[11] A. Zeb, "Comparative analysis of performance of Islamic vis a vis conventional banking of Pakistan during global financial crisis," Journal of Islamic Banking and Finance, vol. 32, no. 1, pp. 45-55, 2015.

[12] A. Emrouznejad, G.-1. Yang, "A survey and analysis of the first 40 years of scholarly literature in DEA: 1978-2016," Socio-Economic Planning Sciences, vol. 6, pp. 4-8, 2017.

[13] Bank Negara Malaysia, "The Financial Stability and Payment Systems Report (Various Years)," Bank Negara Malaysia, 2014-2019.

[14]Z. Saieed, "DFI merger talks begin," The Star, Star Media Group, 2019.

[15]Bank Negara Malaysia. "Shariah Advisory Council," 16 August 2021; https://www.sacbnm.org/.

[16] M. F. Basri, "The performance of Malaysian Islamic banking industry and the impact of foreign Islamic banks," Doctoral thesis, Durham University Business School, Durham University, United Kingdom, 2016.

[17] M. J. Farrell, "The measurement of productive efficiency," Journal of the Royal Statistical Society: Series A (General), vol. 120 , no. 3, pp. 253-281, 1957.

[18]A. G. P. Commission, "On efficiency and effectiveness: some definitions," Productivity Commission Staff Note, 2013.

[19] S. Kumar, R. Gulati, "An examination of technical, pure technical, and scale efficiencies in Indian public sector banks using data envelopment analysis," Eurasian Journal of Business and Economics, vol. 1, no. 2, pp. 33-69, 2008.

[20] M. Mostafa, "Modelling the efficient of GCC banks: A Data Envelopment Analysis approach," International Journal of Productivity and Performance Management, vol. 56, no. 7, pp. 623-643, 2007.

[21] D. Aigner, C. K. Lovell, P. Schmidt, "Formulation and estimation of stochastic frontier production function models," Journal of econometrics, vol. 6, no. 1, pp. 21-37, 1977.

[22] A. N. Berger, D. B. Humphrey, "Efficiency of financial institutions: International survey and directions for future research," European Journal of Operational Research, vol. 98, no. 2, pp. 175-212, 1997.

[23] S. C. Kumbhakar, C. A. K. Lovell, Stochastic frontier analysis, Cambridge: Cambridge University Press, 2003.

[24] M. Jawada, E. Siwar, "The Determinants Of Technical Efficiency: Case Of Islamic Banks," Australian Journal of Basic and Applied Sciences, vol. 11, no. 6, pp. 12-24, 2017.

[25] M. D. Miah, H. Uddin, "Efficiency and stability: A comparative study between Islamic and conventional banks in GCC countries," Future Business Journal, vol. 3, no. 2, pp. 172-185, 2017.
[26] A. Charnes, W. W. Cooper, E. Rhodes, "Measuring the efficiency of decision making units," European journal of operational research, vol. 2, no. 6, pp. 429-444, 1978.

[27] W. W. Cooper, L. M. Seiford, K. Tone, Data Envelopment Analysis: A comprehensive text with models, applications, references and DEA-solver software: Second edition, New York: Springer, 2007.

[28] T. J. Coelli, D. P. Rao, C. J. O'Donnell, G. E. Battese, An introduction to efficiency and productivity analysis, 2nd ed., New York: Springer Science + Business Media Inc., 2005.

[29] N. K. Avkiran, “An application reference for Data Envelopment Analysis in branch banking: Helping the novice researcher," International Journal of Bank Marketing, vol. 17, no. 5, pp. 206-220, 1999.

[30] Lutfi, Suyatno, "Determinants of Bank Efficiency: Evidence from Regional Development Banks," Jurnal Ekonomi Malaysia, vol. 53, no. 3, pp. 59-74, 2019.

[31] I. Widiarto, A. Emrouznejad, "Social and financial efficiency of Islamic microfinance institutions: A Data Envelopment Analysis application," Socio-Economic Planning Sciences, vol. 50, pp. 1-17, 2015.

[32] V. Efendic, N. Hadziahmetovic, "The social and financial efficiency of microfinance institutions: the case of Bosnia and Herzegovina," South East European Journal of Economics and Business (Online), vol. 12, no. 2, pp. 85-101, 2017.

[33] M. F. Basri, A. A. Muhamat, M. N. Jaafar, "The efficiency of Islamic banks in Malaysia: Based on DEA and Malmquist productivity index," Journal of Emerging Economies \& Islamic Research, vol. 6, no. 3, pp. 1-14, 2018.

[34]Y. Gao, M. Zhang, X. Liu, "Study on the efficiency measurements and influence factors of development financial institutions," Emerging Markets Finance and Trade, vol. 56, no. 8, pp. 1765-1780, 2020.

[35] J.-E. Sturm, B. Williams, "Foreign bank entry, deregulation and bank efficiency: Lessons from the Australian experience," Journal of Banking \& Finance, vol. 28, no. 7, pp. 1775-1799, 2004.

[36]A. Charnes, Data Envelopment Analysis: Theory, methodology and applications, Massachusetts: Kluwer Academic Publishers, 1994.

[37] A. Emrouznejad, A. L. Anouze, "Data envelopment analysis with classification and regression tree-a case of banking efficiency," Expert Systems, vol. 27, no. 4, pp. 231-246, 2010.

[38] M. Alharthi, "The determinants of efficiency, profitability and stability in the banking sector: A comparative study of islamic, conventional and socially responsible banks," Doctoral thesis, Faculty of Business, Plymouth University, United Kingdom, 2016.

[39] A. G. Noulas, "Deregulation and operating efficiency: the case of the Greek banks," Managerial Finance, vol. 27, no. 8, pp. 35-47, 2001.

[40]F. Sufian, "The efficiency of Islamic banking industry: A non-parametric analysis with non-discretionary input variable," Islamic economic studies, vol. 14, no. 1, pp. 53-78, 2007. 
[41] S. H. Z. Forughi, "An analysis on the efficiency and productivity of the Australian banking sector with a specific emphasis on the global financial crisis (2007-2009)," Master thesis, School of Accounting and Finance, University of Wollongong, Australia, 2012.

[42] L. M. Seiford, R. M. Thrall, "Recent developments in DEA: the mathematical programming approach to frontier analysis," Journal of econometrics, vol. 46, no. 1-2, pp. 7-38, 1990.

[43] R. D. Banker, A. Charnes, W. W. Cooper, "Some models for estimating technical and scale inefficiencies in Data Envelopment Analysis," Management Science, vol. 30, no. 9, pp. 1078-1092, 1984.

[44]T. J. Coelli, "Measurement of total factor productivity growth and biases in technological change in Western Australian agriculture," Journal of Applied Econometrics, vol. 11, no. 1, pp. 77-91, 1996.

[45]A. Akdogan, "Data Envelopment Analysis and an Application in the Tomato Sector in Turkey," Master thesis, School of Economic Sciences, Washington State University, United States of America, 2019.

[46] A. Boussofiane, R. G. Dyson, E. Thanassoulis, "Applied Data Envelopment Analysis," European Journal of Operational Research, vol. 52, no. 1, pp. 1-15, 1991.

[47] B. Golany, Y. Roll, "An application procedure for DEA," Omega, vol. 17, no. 3, pp. 237-250, 1989.

[48] R. G. Dyson, R. Allen, A. S. Camanho, V. V. Podinovski, C. S. Sarrico, E. A. Shale, "Pitfalls and protocols in DEA,"
European Journal of Operational Research, vol. 132, no. 2, pp. 245-259, 2001.

[49] W. F. Bowlin, "Measuring performance: An introduction to Data Envelopment Analysis (DEA)," The Journal of Cost Analysis, vol. 15, no. 2, pp. 3-27, 1998.

[50] A. I. Ali, L. M. Seiford, "The mathematical programming approach to efficiency analysis," The Measurement of Productive Efficiency: Techniques and Applications, Harold O. Fried, Shelton S. Schmidt and C. A. K. Lovell, eds., pp. 120-159, New York: Oxford University Press, 1993.

[51] R. Bahrini, "Efficiency analysis of Islamic banks in the Middle East and North Africa region: A bootstrap DEA approach," International Journal of Financial Studies, vol. 5, no. 1, pp. 7, 2017.

[52]F. Alqahtani, D. G. Mayes, K. Brown, "Islamic bank efficiency compared to conventional banks during the global crisis in the GCC region," Journal of International Financial Markets, Institutions and Money, vol. 51, pp. 58-74, 2017.

[53]H. Jiang, Y. He, “Applying data envelopment analysis in measuring the efficiency of Chinese listed banks in the context of macroprudential framework," Mathematics, vol. 6, no. 10 , pp. $184,2018$.

[54]R. Anto, I. R. D. Pangestusti, E. N. Purwandari, "Determinants of Bank Efficiency in ASEAN5: Size as a Control Variable," Universal Journal of Accounting and Finance, vol. 9, no. 4, pp. 542-547, 2021. DOI: 10.13189/ujaf.2021.090402 